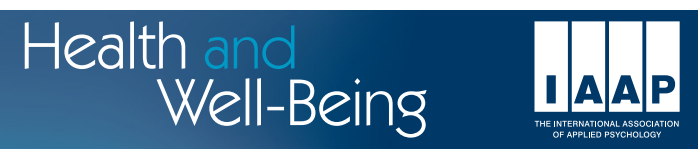

APPLIED PSYCHOLOGY: HEALTH AND WELL-BEING, 2012, 4 (2), 240-260

doi:10.1111/j.1758-0854.2012.01072.x

\title{
Awareness of the Historical Role of the Church and Change in Self-Esteem among Older African Americans
}

\author{
Neal Krause* and R. David Hayward \\ University of Michigan, USA
}

\begin{abstract}
The purpose of this study is to see if greater awareness of the historical role of the church in the black community is associated with a greater sense of selfworth among older African Americans. A latent variable model is evaluated that contains the following core hypotheses: (1) older blacks who go to church more often will receive more spiritual support (i.e. encouragement to adopt religious teachings and beliefs) from fellow church members; (2) greater spiritual support is associated with greater awareness of the role that has been played by the church in the black community; and (3) greater awareness of the historical role of the church is associated with a greater sense of self-worth. Findings from a nationwide survey of older African Americans provide support for each of these linkages. Greater confidence may be placed in the findings because they are based on data that have been gathered at more than one point in time.
\end{abstract}

\section{INTRODUCTION}

Research on self-esteem has dominated the social psychological landscape since the inception of the discipline. A good deal of the early work was theoretical in nature. For example, William James (1892/1961) highlighted the central role that self-esteem plays in social life when he argued that, "the emotion that beckons me on is indubitably the pursuit of an ideal social self, of a self that is at least worthy of approving recognition by the highest possible judging companion" (p. 59; emphasis in the original). But it wasn't long before empirical research on self-esteem began to appear (Hoffman, 1923). During the ensuing years, research on self-esteem grew to the point where researchers now claim that, "It is almost axiomatic in social psychology that people seek to maintain, enhance, and protect their self-esteem" (Crocker \& Park, 2003, p. 291).

* Address for correspondence: Neal Krause, Department of Health Behavior and Health Education, School of Public Health, University of Michigan, 1415 Washington Heights, Ann Arbor, MI 48109-2029, USA. Email: nkrause@umich.edu

(C) 2012 The Authors. Applied Psychology: Health and Well-Being (C) 2012 The International Association of Applied Psychology. Published by Blackwell Publishing Ltd., 9600 Garsington Road, Oxford OX4 2DQ, UK and 350 Main Street, Malden, MA 02148, USA. 
Because self-esteem occupies such a central role in social life it is not surprising to find that a number of studies have been conducted to see if it is associated with better physical and mental health. Considerable evidence suggests that this may be so. A number of researchers report that a stronger sense of self-worth is associated with better mental health (e.g. SachsEricsson et al., 2010), better physical health (Reitzes \& Mutran, 2006), and the adoption of a wide range of beneficial health behaviors, including greater physical activity (Dergance, Mouton, Lichtenstein, \& Hazuda, 2005) and better eating habits (Lucas, Orshan, \& Cook, 2000). However, some investigators question whether claims regarding the health-related benefits of selfesteem are valid (Baumeister, Campbell, Krueger, \& Vohs, 2003).

If a strong sense of self-esteem is associated with better health, then it is important to identify the factors that bolster this potentially important psychological resource. There is an especially pressing need for research on self-esteem among older people because a growing number of studies indicate that feelings of self-worth decline precipitously in the later stages of the life course. More specifically, Orth, Trzesniewski, and Robins (2010) recently found that self-esteem increases during young and middle adulthood but then falls off sharply after age 60 or so. Moreover, it is especially important for the purposes of the current study to note that these researchers report that the decline of self-esteem in late life is more evident among older blacks than older whites. Since the overall health status of older blacks is less favorable than that of older whites (Federal Interagency Forum on Aging Related Statistics, 2010), identifying social and psychological factors that improve and maintain better health among older African Americans holds out the promise of lowering the rapidly escalating health care costs that are borne by one of our most economically challenged minority groups.

A careful reading of the growth curve analysis that was conducted by Orth et al. (2010) suggests that even though there was a sharp decline in self-esteem among older blacks taken as a whole there was also significant individual variation around this general trajectory. This suggests that all older blacks do not experience declining self-esteem as they move through the latter stages of the life course. Because some older African Americans are able to retain a strong feeling of self-worth it is imperative that we learn more about the resources that enable them to do so. Although older blacks are likely to rely on a number of strategies to enhance their feelings of self-worth, the purpose of the current study is to examine whether involvement in religion may at least partly fulfill this important function.

Research consistently shows that older blacks are more deeply involved in religion than older whites (Taylor, Chatters, \& Levin, 2004). More specifically, a number of studies indicate that compared to older whites, older blacks attend worship services more often, pray more frequently, and read the Bible on a more regular basis (Levin, Taylor, \& Chatters, 1994). More- 
over, research further suggests that the social support systems at church are stronger for older blacks than older whites (Krause, 2002a), they are more grateful to God than older whites (Krause, 2012), and they are more likely than older whites to feel that they have been forgiven by God (Krause, 2011). Two key issues arise from this brief literature review. First, religion is a vast multifaceted phenomenon. Second, older blacks are more consistently involved than older whites in many different aspects of religion. As a result, identifying the way in which religion helps some older blacks maintain a strong sense of self-worth may not be as straightforward as it seems.

In the analyses that follow, we focus on one aspect of the church that has been largely overlooked by other investigators - one that may run more deeply in the social currents of the church than others. We propose that the self-esteem of older blacks is bolstered and maintained, at least in part, by a strong belief in the notion that the church has sustained African Americans through centuries of prejudice and discrimination. The reasons for linking beliefs about the wider historical function of the church and self-esteem are relatively straightforward.

The fact that African Americans have encountered a substantial amount of prejudice and discrimination is widely documented in the literature (Williams, Neighbors, \& Jackson, 2003). This research further reveals that racial discrimination tends to erode the self-esteem of African Americans (Williams et al., 2003). But the literature also suggests that the church has historically been a place of solace and strength for African Americans in the face of this adversity. Some time ago, Nelsen and Nelsen (1975) argued that the church has been the center of the African American community since its inception. Due to centuries of hostile experiences in wider American culture, blacks have turned to the church for spiritual, social, and material sustenance primarily because it was the only institution in their community that they built, funded, and wholly owned. As a result, the church became a conduit for the delivery of social services, and the first schools for Black children were located in them. In fact, it is not surprising to find that many of the great political leaders in the black community have strong ties to the church, and many have been members of the clergy (e.g. Martin Luther King, Jr.).

Perhaps no one wrote more on the early history of the church in the black community than W.E.B. Du Bois (2000). Writing in 1887, he concluded that, "The Negro church . . . provides social intercourse, it provides amusement of various kinds, it serves as a newspaper and intelligence bureau, it supplants the theater, it directs the picnic and excursion, it furnishes the music, it introduces the stranger to the community, it serves as a lyceum, library, and lecture bureau - it is, in fine, the central organ of organised life of the American Negro" (p. 21). Later, in 1899, Du Bois (2000) went on to argue that social ties in black churches were even stronger than those found in churches 
in the White community: "Without wholly conscious effort the Negro church has become a center of social intercourse to a degree unknown in white churches even in the country" (p. 34).

Although the observations of Du Bois (2000) were made over a century ago, the central role that the church plays in sustaining African Americans is found in the work of contemporary investigators as well. This theme is especially evident in the work of J. Deotis Roberts (2003), who is a noted black theologian. Roberts (2003) clearly sees the importance of bolstering feelings of self-worth as part of the historical mission of the church in the black community when he points out that, "We must have a sound theological understanding of the nature of the black church if we are to understand its mission.... The church, as a good family, is a fellowship in which every member is 'somebody.' It has always been a place where blacks who have been 'nobodies' through the week have affirmed their dignity as persons. Among members of the body of Christ there is to be togetherness, belongingness, but the dignity of selfhood is to be respected and cultivated" (pp. $80-81$; emphasis in the original). Taken together, the views of Du Bois (2000) and Roberts (2003) suggest that an awareness of and participation in the historical mission of the church serves as a source of dignity, pride, and self-worth for many African Americans.

Other investigators have shown that greater involvement in religion tends to offset the deleterious effects of racial discrimination on psychological distress among blacks (Bierman, 2006; Ellison, Musick, \& Henderson, 2008). However, religious involvement was evaluated with a measure of church attendance alone in Bierman's (2006) study. Ellison and his colleagues used three measures of religion in their study, but they were all general measures as well (Ellison et al., 2008). More specifically, these researchers focused on church attendance, a measure of the amount of guidance provided by religion in daily life, and an index of general social support from fellow church members (e.g. whether they would help out in the future if the need arose). The general nature of the measures that have been used in these studies makes it difficult to identify the precise ways in which religious involvement helps blacks deal with racial adversity. We aim to contribute to the literature by exploring the potentially important influence of a more focused and explicit aspect of religious involvement - whether the church has historically sustained blacks through centuries of racial injustice.

There appears to be only one study in the literature that has attempted to link the wider historical mission of the church in the black community with the well-being of older African Americans. Research by Krause (2004) reveals that believing that the church has sustained black people in the face of racial adversity is associated with greater life satisfaction among older African Americans. An effort is made in the analyses that follow to build on these insights in three potentially important ways. First, although an awareness of 
the historical role of the church in the black community is shaped by a number of factors, we focus on the way in which this consciousness is built up and sustained through spiritual support from fellow church members (i.e. encouragement to adopt religious beliefs and practices). Second, whereas Krause (2004) was concerned with how awareness of the historical role of the church bolsters life satisfaction, we focus instead on how it influences feelings of self-esteem. Third, the study by Krause (2004) was based on cross-sectional data. We use data that were gathered at two points in time in order to explore the ways in which change in awareness of the historical role of the church affects change in feelings of self-worth among older African Americans. A latent variable model was developed in order to pursue these goals. This model, and the theoretical rationale on which it is based, are presented in the next section.

\section{THE HISTORICAL ROLE OF THE CHURCH AND CHANGE IN SELF-ESTEEM AMONG OLDER BLACKS}

Figure 1 contains the latent variable model that is evaluated in this study. Two steps were taken to simplify the presentation of this complex conceptual scheme. First, the elements of the measurement model (i.e. the factor loadings and measurement error terms) are not depicted graphically even though a full

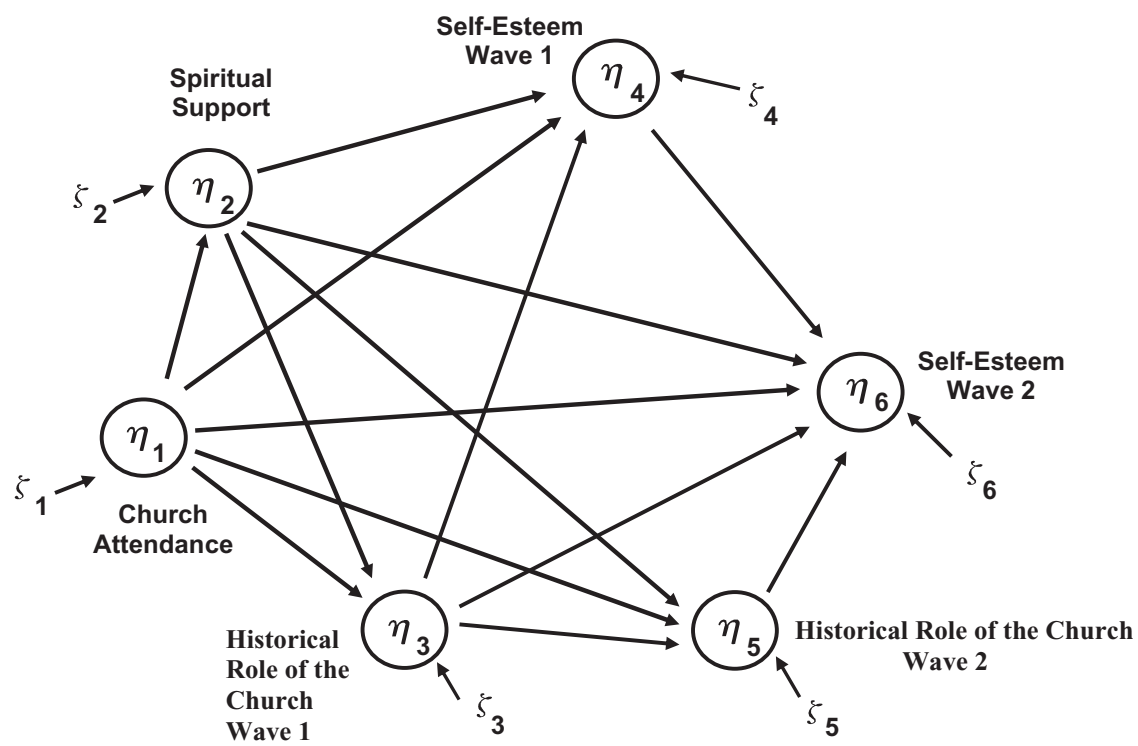

FIGURE 1. Historical role of the church and change in self-esteem. 
measurement model estimated with this conceptual scheme was evaluated empirically. Second, the relationships among the constructs in Figure 1 were estimated after age, sex, and education were included in the model.

Although a number of relationships are estimated in Figure 1, the following linkages capture the theoretical core of this conceptual scheme: (1) older blacks who go to church more often tend to receive more spiritual support from fellow church members; (2) greater spiritual support is, in turn, associated with a greater awareness of the role the church has played in sustaining black people; and (3) greater awareness of the role the church has played in sustaining black people is associated with a stronger sense of self-esteem. A theoretical rationale for each of these relationships is provided below.

\section{Church Attendance and Spiritual Support}

Spiritual support is assistance that is specifically intended to increase the religious commitment, beliefs, and behavior of a fellow church member. There are a number of ways in which church members may exchange spiritual support. For example, they may share their own religious experiences with a co-religionist, they may show them how to apply their religious beliefs in daily life, or they may help them find solutions to problems they encounter by turning to the Bible (Krause, 2008).

There are two closely related reasons why more frequent attendance at worship services should be associated with more spiritual support. The first is straightforward. In order for one person to provide support to another, the recipient must obviously come into contact with the support provider. Attending worship services provides one setting in which this type of contact may take place. Second, and perhaps more important, an individual is not likely to offer spiritual support to a fellow church member until they have developed a relatively close relationship with them. Otherwise, their overtures may be met with resentment (McFadden, Knepple, \& Armstrong, 2003). Attending church more frequently provides the opportunity for social relationships to develop to the point where individuals feel more comfortable discussing personal religious issues with one another.

\section{Spiritual Support and Awareness of the Historical Role of the Church}

African Americans are likely to learn about the historical role of the church in a number of different ways. For example, messages in sermons, hymns, and congregational prayers underscore the ways in which the church has sustained black people down through the years. We propose that informal spiritual support from fellow church members plays a significant part in building this type of consciousness, as well. In order to see why this may be 
so, it is helpful to consider three issues. The first has to do with religious views on the situation of black people in America. As Roberts (2003) points out in his discussion of the evolution of religion in the black church, "Above all, the biblical message of freedom from bondage, the theme of the Exodus, had an immediate appeal" (p. 63). Simply put, issues involving racial injustice figured prominently in the black church since its inception. The second issue involves the extent to which informal interaction in the black church focuses on religious issues. As research by Krause and Bastida (2011) reveals, older blacks are far more likely to exchange spiritual support at church than either older whites or older Mexican Americans. The third issue has to do with the specific ways in which spiritual support is exchanged in the church. As we discuss later in this study, spiritual support is measured, in part, by assessing the extent to which religious experiences are shared informally in the church. If biblical themes involving the slavery of the Jewish people are tightly woven into the fabric of the black religious experience, and if blacks share their religious experiences with each other frequently, then it follows that spiritual support represents an important way in which awareness of the historical role of the church is bolstered and maintained.

Viewed in a more general way, this theoretical perspective rests on insights that were provided by Berger (1967) in his classic treatise on how religious worldviews are created and maintained. Berger (1967) argued that religious views of the world "are socially constructed and socially maintained. Their continuing reality, both objective ... and subjective, depends upon specific social processes, namely those processes that ongoingly reconstruct and maintain the particular worlds in question" (p. 45; emphasis in the original).

\section{The Historical Role of the Church and Self-Esteem}

There are two reasons why an awareness of the historical role of the church is likely to bolster the self-esteem of older African Americans. The first may be found in the widely cited study of the church in the black community by Lincoln and Mamiya (1990). They argue that the religious foundation of these institutions rests on something they refer to as the black sacred cosmos: "The core values of black culture like freedom, justice, equality, an African heritage, and racial parity at all levels of human intercourse, are raised to ultimate levels and legitimated by the black sacred cosmos" (p. 7). If racial discrimination is widespread (Williams et al., 2003), then being aware of and embracing the history of an institution that is built on the black sacred cosmos should go a long way toward bolstering and restoring feelings of self-worth that have been eroded by centuries of racial injustice.

The second reason why awareness of the historical role of the church should shore up feelings of self-worth among older blacks may be found in the basic tenets of social identity theory. As Oyserman (2007) points out, 
social identities involve "a positive feeling of being included in some groups, a valenced affective response to being excluded from other groups, and concomitant positive feelings about ingroup defining attributes" (p. 434). Being able to identify with, and be part of, an institution that has been a bastion of solace and sustenance in a hostile social world should foster a deep sense of pride about oneself and one's group. This is why Oyserman (2007) goes on to argue that social identities lie at the very heart of the self concept.

A significant feature of the model depicted in Figure 1 arises from the fact that an emphasis is placed on evaluating the relationship between awareness of the historical role of the church and self-esteem with data that have been gathered at more than one point in time. As Menard (1991) points out, there are a number of different ways to analyze this type of survey data. In fact, he identifies four "pure" longitudinal models (Menard, 1991, p. 59). The model depicted in Figure 1 is among them. In this type of conceptual scheme, change in the dependent variable is expressed in terms of change in the independent variable. The logic of this specification is straightforward: if the level of one variable (i.e. self-esteem) depends upon the level of a second variable (i.e. awareness of the historical role of the church), then if the second variable changes, the first variable must also change. Menard (1991) goes on to point out that many researchers express their hypotheses in terms of this model but unknowingly test a different specification. The model depicted in Figure 1 is especially useful because it addresses one (but not all) of the criteria for establishing causality by assessing whether change in the independent variable is associated with change in the outcome over time (Bradley \& Schaefer, 1998).

\section{METHODS}

\section{Sample}

The data for this study come from the first two waves of interviews in an ongoing nationwide survey of older whites and older African Americans. The study population was defined as all household residents who were either black or white, non-institutionalised, English-speaking, and at least 66 years of age. Geographically, the study population was restricted to all eligible persons residing in the coterminous United States (i.e. residents of Alaska and Hawaii were excluded). Finally, the study population was restricted to currently practicing Christians, individuals who were Christian in the past but no longer practice any religion, and people who were not affiliated with any faith at any point in their lifetime. This study was designed to explore a range of issues involving religion and health. As a result, individuals who 
practice a faith other than Christianity were excluded because it would be too difficult to devise a comprehensive battery of religion measures that would be suitable for individuals of all faiths.

The sampling frame consisted of all eligible persons contained in the beneficiary list maintained by the Centers for Medicare and Medicaid Services (CMS). A five-step process was used to draw the sample from the CMS files (see Krause, 2002b, for a detailed discussion of these steps). Informed consent was obtained verbally from all subjects at all waves of interviews. This was accomplished by reading a statement that explained the rights of study subjects. Following this, study participants were asked to repeat back what they had just been told.

The baseline survey took place in 2001. The data collection for all waves of interviews was conducted by Harris Interactive (New York). A total of 1,500 interviews were completed, face-to-face, in the homes of the study participants. Older African Americans were over-sampled so that sufficient statistical power would be available to assess racial cultural differences in religion. As a result, the Wave 1 sample consisted of 748 older whites and 752 older African Americans. The overall response rate for the baseline survey was 62 per cent.

The Wave 2 survey was conducted in 2004. A total of 1,024 study participants were re-interviewed successfully, 75 refused to participate, 112 could not be located, 70 were too ill to participate, 11 had moved to a nursing home, and 208 were deceased. Not counting those who had died or moved to a nursing home, the re-interview rate for the Wave 2 survey was 80 per cent.

Spiritual support from fellow church members plays a key role in the model that is depicted in Figure 1. When this study was being designed, the members of the research team felt that it did not make sense to ask study participants about spiritual support in church if they don't attend church at all or if they only go to church rarely. Consequently, questions on spiritual support from fellow church members were not administered to older study participants who indicated that they go to church services no more than once or twice a year. After deleting these study participants from the sample, the analyses presented below are based on the responses of 364 older black study participants.

The full information maximum likelihood estimation (FIML) procedure was used to impute missing values in the data. Simulation studies suggest that the FIML procedure is preferable to listwise deletion because listwise deletion may produce biased estimates (Enders, 2010). Moreover, as Graham, Olchowski, and Gilreath (2007) report, FIML is equivalent to more timeconsuming procedures for dealing with item non-response, such as multiple imputation.

Preliminary analyses reveal that the average age of the participants in this sample was 73.9 years ( $S D=5.8$ years), approximately 32 per cent were older 
men, and the average number of years of schooling that were completed by the study participants was 10.5 years $(S D=3.3$ years $)$.

\section{Measures}

Table 1 contains the core measures that were used in the analyses presented below. The procedures that were used to code these indicators are provided in the footnotes of this table.

Historical Role of the Church. Identical items were used to measure the historical role of the church in the black community at the Wave 1 and Wave 2 interviews. The four items that comprise this brief index were developed especially for this study. A high score on these indicators represents study participants who felt that the church has historically been a source of strength and solace in the face of racial injustice. The mean at Wave 1 is 16.1 $(S D=2.8)$ and the mean at Wave 2 is $16.6(S D=2.7)$.

TABLE 1

Core Study Measures

1. Historical Role of the Church-Wave 1 and Wave $2^{\text {a }}$

A. The church has sustained black people in the face of racial injustice.

B. The church provides hope that the struggles of black people will someday be over.

C. I find strength in knowing that the church sustained blacks during slavery.

D. When I experience racial prejudice and racial discrimination, it's comforting to know that God is right there with me.

2. Self-Esteem-Wave 1 and Wave $2^{\mathrm{a}}$

A. I feel I am a person of worth, or at least on an equal plane with others.

B. I feel I have a number of good qualities.

C. I take a positive attitude toward myself.

3. Spiritual Support-Wave $1^{\text {b }}$

A. Not counting Bible study groups, prayer groups, or church services, how often does someone in your congregation share their own religious experiences with you?

B. Not counting Bible study groups, prayer groups, or church services, how often do the examples set by others in your congregation help you lead a better religious life?

C. Not counting Bible study groups, prayer groups, or church services, how often does someone in your congregation help you to know God better?

D. Not counting Bible study groups, prayer groups, or church services, how often does someone in your congregation help you live according to your religious beliefs?

4. Church Attendance-Wave $1^{\mathrm{c}}$

How often do you attend religious services?

a These items are scored in the following manner (coding in parentheses): strongly disagree (1), disagree (2), agree (3), strongly agree (4).

b These items are scored in the following manner: never (1), once in a while (2), fairly often (3), very often (4).

c This item is scored in the following manner: never (1), less than once a year (2), about once or twice a year (3), several times a year (4), about once a month (5), 2 to 3 times a month (6), nearly every week (7), every week (8), several times a week (9).

(C) 2012 The Authors. Applied Psychology: Health and Well-Being (C) 2012 The International Association of Applied Psychology. 
Self-Esteem. The same items were used to assess self-esteem in the Wave 1 and Wave 2 interviews. The three indicators that comprise this measure are from the Rosenberg Self-Esteem Scale (Rosenberg, 1965). These items were identified through a series of exploratory and confirmatory factor analyses by Krause and Borawski-Clark (1994). A high score denotes greater feelings of self-worth. The mean at Wave 1 is $10.7(S D=1.4)$ and the mean at Wave 2 is $10.7(S D=1.5)$.

Spiritual Support. The four indicators that were used to measure spiritual support were taken from the Wave 1 interview. A high score stands for older blacks who report receiving more spiritual support from the members of their congregation. The mean of this short scale is $10.7(S D=3.5)$.

Church Attendance. A widely used item was included in the Wave 1 survey to assess how often older study participants attended worship services in the year prior to the survey. A high score denotes more frequent church attendance. The mean is $7.0(S D=2.0)$.

Demographic Control Measures. Recall that the relationships among the constructs in Figure 1 were estimated after the effects of age, sex, and education were controlled statistically. Age and education were scored in years. In contrast, sex is a binary variable $(1=$ men; $0=$ women $)$. A measure of age was included in the model because, as discussed earlier, research indicates that feelings of self-esteem tend to decline sharply over the course of late life (Orth et al., 2010). Gender was included in the model because some (but not all) studies reveal that males score higher on global self-esteem scales than females (Kling, Hyde, Showers, \& Buswell, 1999). Finally, education was included as a control variable because research indicates that individuals with higher levels of educational attainment tend to have stronger feelings of self-worth (Sinclair et al., 2010).

\section{RESULTS}

The findings from this study are presented below in three sections. The first section contains some technical information about the way in which the study model was estimated. Then, reliability estimates for the multiple item study measures are provided in section two. Finally, the substantive study findings are presented in section three.

\section{Assessing the Fit of the Model to the Data}

The model depicted in Figure 1 was evaluated using Version 8.80 of the LISREL statistical software program (du Toit and du Toit, 2001). However, 
researchers who use this estimator must assume that the observed indicators in a study model have a multivariate normal distribution. Preliminary tests (not shown here) revealed that this assumption had been violated in the current study. Although there are a number of ways to deal with departures from multivariate normality, the straightforward approach provided by du Toit and du Toit (2001) was followed here. These investigators report that departures from multivariate normality can be handled by converting raw scores on the observed indicators to normal scores prior to estimating the model (du Toit and du Toit, 2001, p. 143). Consequently, the analyses presented below are based on observed indicators that have been normalised.

As noted earlier, the FIML algorithm was used to handle item nonresponse. When this procedure is used, the LISREL software program provides only two goodness-of-fit measures. The first is the full information maximum likelihood chi-square statistic $($ chi-square $=287.933$; with 178 degrees of freedom; $p<.05$ ). However, this measure of fit is widely known to be unduly affected by large sample sizes, such as the one in the present study. Better insight into the fit of the model to the data is provided by the second indicator, the root mean square error of approximation (RMSEA). The RMSEA estimate for the final model that was evaluated in this study is .041. As Kelloway (1998) points out, estimates below .050 represent a very good fit to the data.

\section{Reliability Estimates for the Multiple Item Measures}

Table 2 contains the factor loadings and measurement error terms that were derived from estimating the study model. These coefficients are important because they provide important information about the reliability of the multiple item study measures. Kline (2005) recommends that items with standardised factor loadings in excess of .600 tend to have reasonably good reliability. As the data in Table 2 indicate, the standardised factor loadings range from .577 to .936 . Only two indicators had standardised factor loadings below .600 (i.e. .577 and .591 ), but the difference between these coefficients and the desired .600 level is trivial. Consequently, it appears that the multiple item measures in this study have good psychometric properties.

Although the factor loadings and measurement error terms associated with the observed indicators provide useful information about the reliability of each item, it would also be helpful to know something about the reliability for the multiple item scales as a whole. Fortunately, it is possible to compute these reliability estimates with a formula provided by DeShon (1998). This procedure is based on the factor loadings and measurement error terms in Table 2. Applying the procedures described by DeShon (1998) to these data yields the following reliability estimates for the multiple item constructs in Figure 1: Spiritual support (.893), the historical role of the church-Wave 1 
TABLE 2

Measurement Error Parameter Estimates for Multiple Item Study Measures $(N=364)$

\section{Construct}

Factor Loading ${ }^{a}$

Measurement Error ${ }^{b}$

1. Historical Role of the Church-Wave 1
A. Sustained black people ${ }^{\mathrm{c}}$
.591
.651
B. Struggles of black people
.793
.372
C. Sustained blacks during slavery
.717
.485
D. When I experience prejudice
.657
.568

2. Historical Role of the Church-Wave 2
A. Sustained black people
B. Struggles of black people
C. Sustained blacks during slavery
D. When I experience prejudice

.577

.667

3. Self-Esteem-Wave 1
A. I am a person of worth
B. Number of good qualities
C. Take a positive attitude

.905

.181

4. Self-Esteem-Wave 2
A. I am a person of worth
B. Number of good qualities
C. Take a positive attitude

.840

.294

.936

5. Spiritual Support-Wave 1
A. Share religious experiences
.658
B. Lead a better religious life
.865
C. Help you know God better
.868
D. Live according to beliefs
.884

\footnotetext{
a Factor loadings are from the completely standardised solution. The first-listed item for each latent construct was fixed at 1.0 in the unstandardised solution.

b Measurement error terms are from the completely standardised solution. All factor loadings and measurement error terms are significant at the .001 level.

${ }^{c}$ Item content is paraphrased for the purpose of identification. See Table 1 for the complete text of each indicator.
}

(.786), self-esteem-Wave 1 (.927), the historical role of the church-Wave 2 (.793), and self-esteem-Wave 2 (.921). Taken as a whole, these estimates suggest that the measures that are used in the current study have an acceptable level of reliability.

\section{Substantive Findings}

Table 3 contains the substantive findings that emerged from estimating the study model. Taken as a whole, the results provide support for all of the core hypotheses. More specifically, the data indicate that older African Americans who go to church more often tend to receive more spiritual support from their 


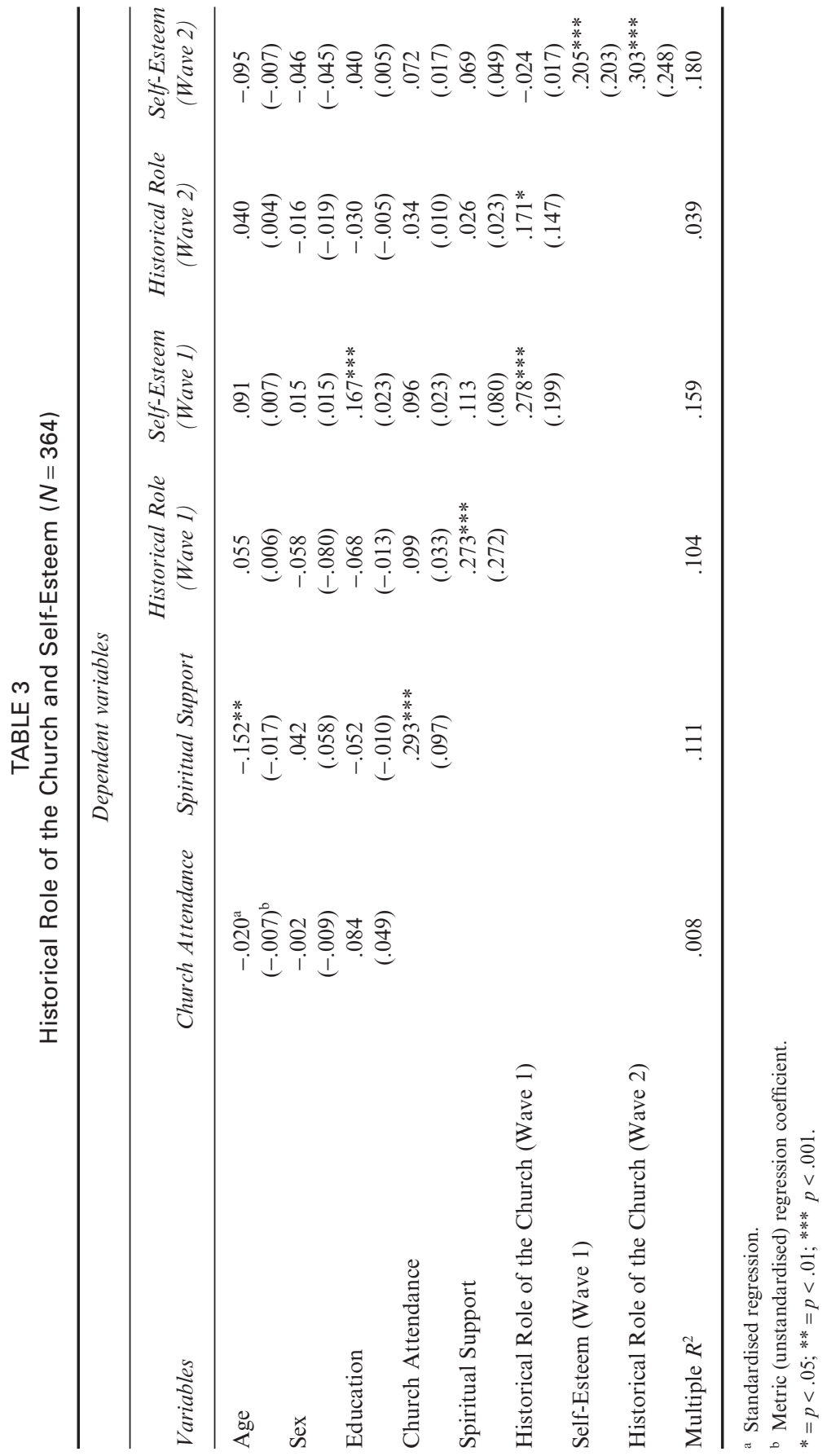


rank-and-file church members $($ Beta $=.293 ; p<.001)$. The results further reveal that older blacks who receive more spiritual support are more likely to believe that the church has sustained African Americans (Beta $=.273$; $p<.001)$. The findings suggest that greater awareness of the historical role of the church at Wave 1 is, in turn, associated with greater feelings of self-worth at Wave $1(\mathrm{Beta}=.278 ; p<.001)$. Finally, and perhaps most important, the data reveal that greater awareness of the role of the church at Wave 2 is associated with a stronger sense of self-esteem at Wave 2 (Beta $=.303$; $p<.001)$. Viewed in a more general way, this relationship suggests that change in awareness of the historical role of the church is associated with change in self-esteem over time.

The data in Table 3 provide additional information about the nature of the relationship between awareness of church history and self-esteem over time. As we have just pointed out, the relationship between the Wave 1 measures of these constructs is significant and the relationship between the Wave 2 measures is statistically significant, as well. However, the lagged effect is not (i.e. the relationship between awareness of church history at Wave 1 and selfesteem at Wave 2: Beta $=-.024 ; n s$ ). Recall that three years transpired between the Wave 1 and Wave 2 surveys. Taken as a whole, the data in Table 3 indicate that rather than emerging slowly over the course of three years (as reflected in the lagged effect), the effects of awareness of church history tend to take place rather quickly (as reflected in the relationships between these measures within each time period).

Because very little empirical research has been done with awareness of the historical role of the church, it might be helpful to review one more finding involving this construct. The data suggest that the Wave 1 measure of church history is significantly associated with the Wave 2 measure $($ Beta $=.171 ; p<.001)$. However, the magnitude of this relationship is not very strong, suggesting that awareness of church history is not highly stable over time.

One of the advantages that is associated with latent variable modeling has to do with the fact that it is possible to compute the direct, indirect, and total effects that operate through a conceptual scheme. An example will help clarify the meaning of these terms. The model in Figure 1 specifies that more frequent church attendance is associated with more spiritual support and more spiritual support is, in turn, associated with greater awareness of the historical role that the church has played in the black community. Stated in a more technical way, this means that attendance at worship services affects awareness of the historical role of the church indirectly through spiritual support. When the indirect effect of church attendance is added to the direct effect that was discussed above, the resulting total effect provides a better vantage point for gauging the overall influence of church attendance in the model. Breaking down the total effects into direct and indirect effects is 
known in the literature as the decomposition of effects (Alwin, 1988). Three decompositions of effects are discussed briefly below.

The first decomposition involves the variables that were used above to describe the nature of this statistical procedure. The data in Table 3 initially appear to suggest that attendance at worship services is not significantly associated with awareness of the historical role of the church at Wave 1 $($ Beta $=.099 ; n s)$. However, further analysis (not shown in Table 3) reveals that the indirect effect of church attendance on the historical role of the church that operates through spiritual support is statistically significant (Beta $=.080 ; p<.01)$. When the direct and indirect effects are summed, the resulting total effect suggests that attending worship services may indeed increase awareness of the historical role of the church at the baseline interview $(.099+.080=.179 ; p<.001)$. Moreover, the fact that the indirect effect captures approximately 44.7 per cent of this relationship (i.e. $.080 / .179=.447$ ) suggests that informal spiritual support among fellow church members plays a significant role in this respect.

The second decomposition of effects involves the relationship between attendance at worship services and feelings of self-worth at Wave 1. According to the data in Table 3, church attendance does not initially appear to influence self-esteem at the baseline interview (Beta $=.096 ; n s)$. But once again, the indirect and total effects provide a different view. More specifically, further analysis (not shown in Table 3 ) indicates that the indirect effect of church attendance on self-esteem that operates through spiritual support and awareness of the historical role of the church is statistically significant $($ Beta $=.083 ; p<.01)$. When the direct and indirect effects are added together, the resulting total effect reveals that more frequent church attendance is associated with a greater sense of self-worth at the baseline survey $(.096+$ $.083=.179 ; p<.001)$. Moreover, nearly half of the total effect (i.e. $46.4 \%$ ) is due to the indirect effects that operate through spiritual support and awareness of the historical role that is played by the church in the black community.

A long-standing principle in social psychology suggests that self-esteem arises from feedback that is provided by significant others (Hoyle, Kernis, Leary, \& Baldwin, 1999). The model that is provided in Figure 1 provides a strategic context for evaluating this principle within the church. More specifically, this perspective would predict that greater spiritual support from fellow church members should bolster feelings of self-worth among older African Americans. However, data that are provided in Table 3 do not initially appear to support this view $($ Beta $=.113 ; n s)$. Fortunately, a decomposition of effects helps bring the study findings more in line with wellestablished findings. Further analysis (not shown in Table 3) suggests that the indirect effect of spiritual support on self-esteem at Wave 1 that operates through awareness of the historical role of the church is statistically significant (Beat $=.076 ; p<.01)$. When the direct and indirect effects are summed, 
the resulting total effect indicates that greater spiritual support is associated with stronger feelings of self-worth at Wave 1 (Beta $=.189 ; p<.001)$. Put another way, approximately 40.2 per cent of the total effect of spiritual support on self-esteem at the baseline interview is due to the indirect influence of awareness of the historical role of the church $(.076 / .189=.402) .{ }^{1}$

\section{DISCUSSION}

A great deal has been written about the heavy burden that racism has placed on the self-esteem of African Americans. But at the same time, a substantial literature also points to the remarkable resiliency of the black people (Paris, 1995). Although this resilience arises from a number of factors, a good deal of attention has been paid to the role of the church (Roberts, 2003). However, the precise ways in which the church fulfills this role by bolstering the selfesteem of African Americans has not been subject to sufficient empirical evaluation. The purpose of the current study has been to show how one under-studied aspect of church involvement (i.e. awareness of the historical role of the church in the black community) arises and how it may help bolster and maintain feelings of self-worth among older African Americans. It is especially important to explore these issues among older blacks specifically because they came of age during a time when prejudice and discrimination were more overt in American society.

The data from the current study tend to highlight the potentially important influence that awareness of the historical role of the church may have on the black psyche. More specifically, the findings indicate that more frequent church attendance is associated with receiving more spiritual support from fellow church members, greater spiritual support is associated with greater awareness of the role the church has played in the black community, and greater awareness of the role that has been played by the church is associated with a stronger sense of self-worth. Greater confidence can be placed in the findings involving the historical role of the church and self-esteem because estimation of this relationship was subject to a more empirically demanding test. By statistically controlling for the historical role of the church and self-esteem at the baseline interview, we were able to show that increases in the awareness of the role played by the church over time are associated with increases in feelings of self-worth over time. We are not aware of any other study that has provided empirical support for this view.

\footnotetext{
1 There is some evidence that older blacks may give more socially desirable responses when they are being interviewed by whites (Ellison, McFarland, \& Krause, 2011). The analyses in the current study repeated after a measure contrasting white and black interviewers was included in the study model. Only trivial differences emerged in the findings and none of the conclusions reported above changed in any way.
} 
Even though the findings from the current study may have made a contribution to the literature, a considerable amount of work remains to be done. For example, the model that was developed for the current study focused exclusively on how awareness of the role the church has historically played arises within the church. But it is unlikely that forces within the church are solely responsible for raising this type of consciousness. We suspect that the family may play an important role in raising awareness about the historical role of the church but data were not available to pursue this possibility. Exploring the potentially important role of the family should be a high priority in future research. A measure of the extent to which study participants have been personally exposed to racial discrimination was not available in our study. Having this type of measure in a study is important for the following reason. Considerable research outside the context of racism indicates that the effects of coping resources become more pronounced as exposure to stress increases (Wheaton, 1985). If exposure to racial discrimination is viewed as a stressor and historical awareness of the role of the church is considered to be a coping resource, then having data on personal exposure to discrimination would make it possible to see if awareness of the historical importance of the church exerts an increasingly stronger effect on self-esteem as personal exposure to racism increases. Exploring the interface between variation in personal exposure to racism and the stress-buffering effect of awareness of the historical role of the church should also be an important issue to address in the future. There is also some evidence that racial/ethnic identity tends to buffer the effects of racial/ethnic discrimination on mental health (Mossakowski, 2003). Unfortunately, measures of racial/ethnic identity were not available in the current study. Consequently, it is important for researchers to assess whether the effects of awareness of the historical role of the church on self-esteem are stronger for older blacks who identify more closely with their race.

In the process of exploring new areas of research, investigators should also pay careful attention to the limitations in the current study. One shortcoming should be mentioned here. Although the data in this study were gathered at more than one point in time, we still cannot claim to have shown that change in awareness of the historical role of the church "causes" increases in selfesteem. This kind of assertion can only be proven when the data have been gathered with an experimental research design.

C. Wright Mills (1959), a classic social theorist, argued that, "Neither the life of an individual nor the history of a society can be understood without understanding both" (p. 3). Unfortunately, social psychologists have paid relatively little attention to the role of history in the research they do. When viewed at the broadest level, the goal of the current study was to address this imbalance in the literature by bringing one facet of history (i.e. awareness of the historical role that has been played by the church) to the foreground to 
show how it influences the individual self-perceptions of older blacks. We hope the theoretical perspective we have developed and the empirical findings we have provided encourage other investigators to delve more deeply into the influence of history on the lives of older African Americans.

\section{ACKNOWLEDGEMENTS}

This research was supported by grants from the National Institute on Aging (RO1 AG 014749) and the John Templeton Foundation.

\section{REFERENCES}

Alwin, D.F. (1988). Structural equation models in research on human development and aging. In K.W. Schaie, R.T. Campbell, W. Meredith, \& S.C. Rawlings (Eds.), Methodological issues in aging research (pp. 71-170). New York: Springer.

Baumeister, R.F., Campbell, J.D., Krueger, J.I., \& Vohs, K.D. (2003). Does high self-esteem cause better performance, interpersonal success, happiness, or healthier lifestyles? Psychological Science in the Public Interest, 4, 1-44.

Berger, P.L. (1967). The sacred canopy: Elements of a sociological theory. New York: Doubleday.

Bierman, A. (2006). Does religion buffer the effects of discrimination on mental health? Differing effects by race. Journal for the Scientific Study of Religion, 45, $551-565$.

Bradley, W.J., \& Schaefer, K.C. (1998). The uses and misuses of data and models: The mathematization of the human sciences. Thousand Oaks, CA: Sage.

Crocker, J., \& Park, L.E. (2003). Seeking self-esteem: Construction, maintenance, and protection of self-worth. In M.R. Leary \& J.P. Tangney (Eds.), Handbook of self-identity (pp. 291-313). New York: Guilford.

Dergance, J.M., Mouton, C.P., Lichtenstein, M.J., \& Hazuda, J.P. ( 2005). Potential mediators of ethnic differences in physical activity in older Mexican American and European Americans: Results from the San Antonio Longitudinal Study on Aging. Journal of the American Geriatrics Society, 53, 1240-1247.

DeShon, R.P. (1998). A cautionary note on measurement error correlations in structural equation models. Psychological Methods, 3, 412-423.

Du Bois, W.E.B. (2000). Du Bois on religion (P. Zuckerman, Ed.). New York: Alta Mira Press.

du Toit, M., \& du Toit, S. (2001). Interactive LISREL: User's guide. Lincolnwood, IL: Scientific Software International.

Ellison, C.G., McFarland, M.J., \& Krause, N. (2011). Measuring religiousness among African Americans: Exploring race-of-interviewer effects. Review of Religious Research, 53, 65-84.

Ellison, C.G., Musick, M.A., \& Henderson, A.K. (2008). Balm of Gilead: Racism, religious involvement, and psychological distress among African-American adults. Journal for the Scientific Study of Religion, 47, 291-309.

Enders, C.K. (2010). Applied missing data analysis. New York: Guilford.

(C) 2012 The Authors. Applied Psychology: Health and Well-Being (C) 2012 The International Association of Applied Psychology. 
Federal Interagency Forum on Age Related Statistics (2010). Older Americans 2010: Key indicators of well-being. Washington, DC: U.S Government Printing Office.

Graham, J.W., Olchowski, A.E., \& Gilreath, T.D. (2007). How many imputations are really needed? Clarifications of multiple imputation theory. Prevention Science, 8 , 206-213.

Hoffman, G.J. (1923). An experiment in self-estimation. Journal of Abnormal Psychology and Social Psychology, 18, 43-49.

Hoyle, R.H., Kernis, M.H., Leary, M.R., \& Baldwin, M.W. (1999). Selfhood: Identity, esteem, regulation. Boulder, $\mathrm{CO}$ : Westview.

James, W. (1892/1961). Psychology: The briefer course. New York: Harper \& Row.

Kelloway, E.K. (1998). Using LISREL for structural equation modeling. Thousand Oaks, CA: Sage.

Kline, R.B. (2005). Principles and practice of structural equation modeling. New York: Guilford.

Kling, K.C., Hyde, J.S., Showers, C.J., \& Buswell, B.N. (1999). Gender differences in self-esteem: A meta-analysis. Psychological Bulletin, 125, 470-500.

Krause, N. (2002a). Exploring race differences in a comprehensive battery of churchbased social support measures. Review of Religious Research, 44, 126-149.

Krause, N. (2002b). Church-based social support and health in old age: Exploring variations by race. Journal of Gerontology: Social Sciences, 57B, S332-S347.

Krause, N. (2004). Common facets of religion, unique facets of religion and life satisfaction among older African Americans. Journal of Gerontology: Social Sciences, 59B, S109-S117.

Krause, N. (2008). Aging in the church: How social relationships affect health. West Conshohocken, PA: Templeton Foundation Press.

Krause, N. (2011). Studying forgiveness among older whites, older blacks, and older Mexican Americans. Under review at the Journal of Psychology and Christianity.

Krause, N. (2012). Feelings of gratitude toward God among older whites, older African Americans, and older Mexican Americans. Research on Aging, 34, 156173.

Krause, N., \& Bastida, E. (2011). Social relationships in the church during late life: Assessing differences between older African Americans, whites, and Mexican Americans. Review of Religious Research, 53, 41-63.

Krause, N., \& Borawski-Clark, E. (1994). Clarifying the functions of social support in later life. Research on Aging, 16, 251-279.

Levin, J.S., Taylor, R.J., \& Chatters, L.M. (1994). Race and gender differences in religiosity among older adults: Findings from four national surveys. Journal of Gerontology: Social Sciences, 49, S137-S145.

Lincoln, C.E., \& Mamiya, L.H. (1990). The black church in the African American experience. Durham, NC: Duke University Press.

Lucas, J.A., Orshan, S.A., \& Cook, F. (2000). Determinants of health-promoting behavior among women ages 65 and above living in the community. Scholarly Inquiry for Nursing Practice, 14, 77-100.

McFadden, S.H., Knepple, A.M., \& Armstrong, J.A. (2003). Length and locus of friendship influence, church members' sense of social support, and comfort with sharing emotions. Journal of Religious Gerontology, 15, 39- 55. 
Menard, S. (1991). Longitudinal research (Sage University Paper Series on Quantitative Applications in the Social Sciences, 76). Newbury Park, CA: Sage.

Mills, C.W. (1959). The sociological imagination. New York: Oxford University Press.

Mossakowski, K.N. (2003). Coping with perceived discrimination: Does ethnic identity protect mental health? Journal of Health and Social Behavior, 44, 318-331.

Nelsen, H.M., \& Nelsen, A.K. (1975). Black church in the sixties. Lexington, KY: University of Kentucky Press.

Orth, U., Trzesniewski, K.H., \& Robins, R.W. (2010). Self-esteem development from young adulthood to old age: A cohort-sequential longitudinal study. Journal of Personality and Social Psychology, 98, 645-658.

Oyserman, D. (2007). Social identity and self-regulation. In A.W. Kruglanski \& E.T. Higgens (Eds.), Social psychology: Handbook of basic principles (pp. 432-453). New York: Guilford.

Paris, P.J. (1995). The spirituality of African peoples: The search for a common moral discourse. Minneapolis, MN: Fortress Press.

Reitzes, D.C., \& Mutran, E.J. (2006). Self and health: Factors that encourage self-esteem and functional health. Journal of Gerontology: Social Sciences, 61B, S44-S51.

Roberts, J.D. (2003). Black religion, black theology (E.M. Goatley, Ed.). Harrisburg, PA: Trinity Press International.

Rosenberg. M. (1965). Society and the adolescent self-image. Princeton, NJ: Princeton University Press.

Sachs-Ericsson, N., Gayman, M.D., Kendall-Tackett, K., Lloyd, D.A., Medley, A., Collins, N., Corsentino, E., \& Sawyer, K. (2010). The long-term impact of childhood abuse on internalizing disorder among older adults: The moderating role of self-esteem. Aging \& Mental Health, 14, 489-501.

Sinclair, S.J., Blais, M.A., Gansler, D.A., Sandberg, E., Bistis, K., \& LoCicero, A. (2010). Psychometric properties of the Rosenberg Self-Esteem Scale: Overall and across demographic groups living in the United States. Evaluation \& the Health Professions, 33, 56-80.

Taylor, R.J., Chatters, L.M., \& Levin, J. (2004). Religion in the lives of African Americans: Social, psychological, and health perspectives. Thousand Oaks, CA: Sage.

Wheaton, B. (1985). Models for the stress-buffering functions of coping resources. Journal of Health and Social Behavior, 26, 352-364.

Williams, D.R., Neighbors, H.W., \& Jackson, J.S. (2003). Racial/ethnic discrimination and health: Findings from community studies. American Journal of Public Health, 93, 200-208. 